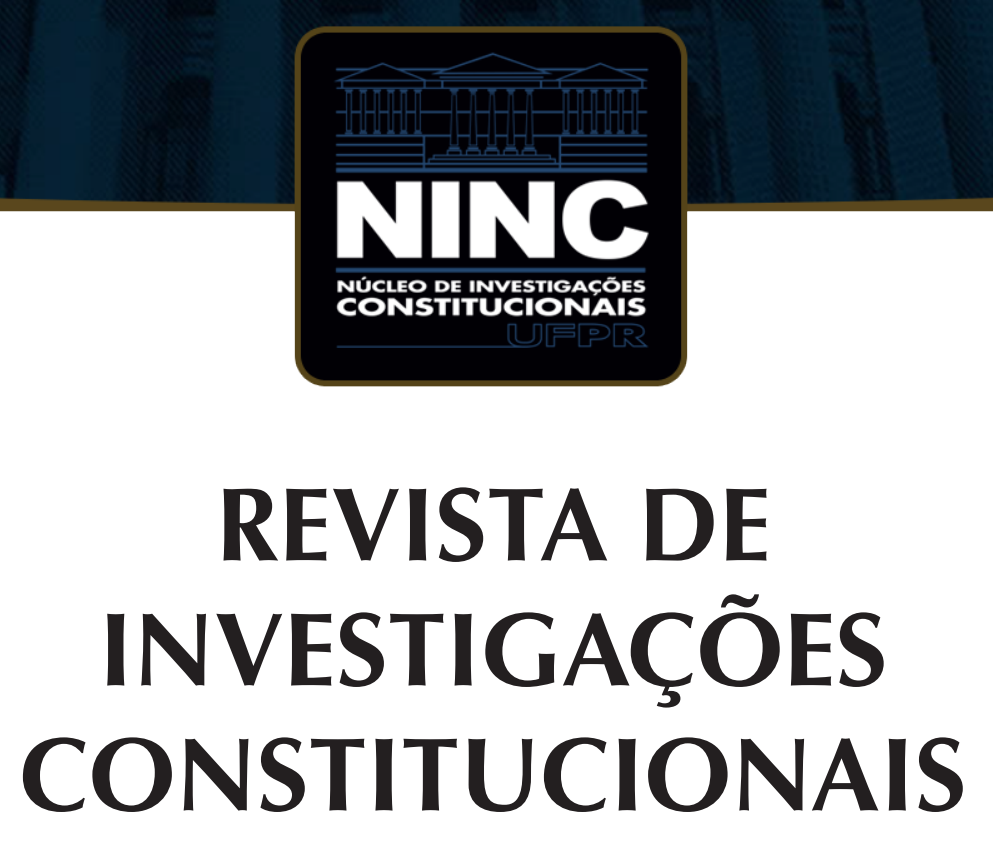

JOURNAL OF CONSTITUTIONAL RESEARCH

vol. 7 | n. 3 | setembro/dezembro 2020 | ISSN 2359-5639 | Periodicidade quadrimestral Curitiba | Núcleo de Investigações Constitucionais da UFPR | www.ninc.com.br 


\title{
Constitutional interpretation and Constitution substitution: oscillating between the juridical and the political
}

\author{
Interpretação constitucional e substituição constitucional: \\ oscilando entre o jurídico e o político
}

LUISA FERNANDA GARCÍA LÓPEZ ${ }^{1, *}$

' Universidad del Rosario (Bogotá, Colombia) luisa.garcia@urosario.edu.co

https://orcid.org/0000-0002-3512-827X

Recebido/Received: 03.06.2020 / June 3 $3^{\text {rd }}, 2020$ Aprovado/Approved: 04.11.2020 / November $4^{\text {th }}, 2020$

Abstract

The concept of constitution substitution is a notion that has not been developed by constituent power, and in that measure, the Colombian Constitutional Court has established a precedent for the amendment process of the Legislative Act, which is performed by congress in order to limit the power of constituted power. In spite the fact that the Court has stated that there are no clauses written in stone, it has forged some fundamental principles and consolidated the defining axes, is what resume the theo ry of substituting. However, constitutional amendments have some limits to what Richard Albert makes a reference and summarize in 4 fundamental characteristics, that should not exceed the constitutional scope. As was pointed out by Albert the power to amend is one above all that does not exceed the scope of what was intended in the constitution, but there may be an intermediate point which he calls dismemberment, which is more than an amendment but does not get to become a structural reform of the constitution. Let's see how Colombia's
Resumo

O conceito de substituição constitucional é uma noção que não foi desenvolvida pelo poder constituinte e, nessa medida, o Tribunal Constitucional colombiano estabeleceu um precedente para o processo de alteração do Ato Legislativo, que é realizado pelo Congresso para limitar o poder do poder constituído. Apesar de o Tribunal ter afirmado que não existem cláusulas escritas em pedra, forjou alguns princípios fundamentais e consolidou os eixos definidores, que é o que retoma a teoria da substituição. No entanto, as emendas constitucionais têm alguns limites a que Richard Albert faz referência, resumindo-os em 4 características fundamentais, que não devem ultrapassar o escopo constitucional. Como foi apontado por Albert, o poder de emendar é aquele que, acima de tudo, não excede o alcance do que foi pretendido na constituição, mas pode haver um ponto intermediário que ele chama de desmembramento, que é mais do que uma emenda, mas não para se tornar uma reforma estrutural da Constituição. Vamos ver como a Constituição da Colômbia e o Tribunal

Como citar esse artigo/How to cite this article: GARCÍA LÓPEZ, Luísa Fernanda. Constitutional interpretation and Constitution substitution: oscillating between the juridical and the political. Revista de Investigações Constitucionais, Curitiba, vol. 7, n. 3, p. 755-771, set./dez. 2020. DOI: 10.5380/rinc.v7i3.74332.

"Principal Professor of Constitutional Law at the Universidad del Rosario (Bogotá, Colombia). PhD in Law from Université de Montpellier I. Master's degree in General Public Law from Université de Montpellier I. Master's degree in International Public Law from Université de Montpellier I. E-mail: luisa.garcia@urosario.edu.co. 
Constitution and the Constitutional Court have set limits to constitutional amendments and exceeded constitutional limits through dismemberment.

Keywords: constitution substitution; constitutional amendment; legislative act; Constitutional Court; original constituent.
Constitucional estabeleceram limites para emendas constitucionais e ultrapassaram os limites constitucionais por meio do desmembramento.

Palavras-chave: substituição constitucional; emenda constitucional; ato legislativo; Corte Constitucional; constituinte originário.

\section{CONTENTS}

1. Introduction; 2. The democratic principle of having jurisdiction and the limits to the capability of amending the constitution; 2.1. The democratic principle as a requisite to reform when amending the constitution; 2.2. The breach of the Democratic principal carries along a Constitution substitution; 3. Judgments on substitutions: oscillating between an amendment and a dismemberment; 3.1. Judgment on constitution substitution; 3.2. Dismemberment and Fast track; 4. Conclusion; 5. References.

\section{INTRODUCTION}

Richard Albert's book "Constitutional amendments" is a reference on how constitutional amendments are transformed or preserved, to protect democracy. Its content and present nature show how such means of amending is a fundamental aspect of contemporary democracies and how constitutional law is an ineludible matter for constitutionalist, today and tomorrow.

Albert highlights an aspect that is highly debated in Colombia, that is to say, the Constitutional Court's ability to interpret it. The creation of the defining axes by the Colombian Constitutional Court, to apply the substitution test is a dogmatic construct that gives the Court the freedom to determine randomly the constitutional text, since the Constitution has no objective parameters on the definition of such defining axes'. It is important to address the extent to which formal control of the Court has become a material control, when the thesis of the substitution of the Constitution (i.e. Constitution substitution) has been used primarily to declare the unconstitutionality of reforms to the Political Charter, pursued by the legislator. To what extent, does Colombia's Constitutional Court, through interpretation, create validity parameters to reform the Constitution? To what degree does this control become a political control?

The Court has jurisdiction to examine if Congress, when exercising the power to reform, incurred in procedural defects or not; besides using the grounds of article 241.1 of the Constitution, it is backed by the difference that there is between the power of the Original Constituent - whose political power is not subject to juridical limits - and that power derived from constituent power bestowed upon the Republic's Congress (art. 374 of Colombia's Political Constitution.), a role that enables the latter to reform

\footnotetext{
1 ALBERT, Richard. Constitutional Amendments Making, breaking, and changing constitutions. New York, Oxford University Press, 2019. p. 153-154.
} 
the constitutional text, but in that measure it is a limited power, subject to the conditions set forth in such aforementioned text. The court has stated that these conditions refer to, not only the reform procedure but also, to the jurisdiction of being a derived constituent. Here, there is relevance in terms of the power to review the reforms to the current constitution, but there is no power to substitute it, in total or partially, temporarily or definitively with another Constitution, which may only be done by the Original Constituent. In this manner, the Court has stated that the judgement to substitute the Constitution has the purpose of reviewing the constitutionality of a Legislative Act. It is not to perform a material control, but rather to know whether o not there was a replacement of the defining axis of the Constitution or of the Constitutional Set. The plaintiff in filing the lawsuit challenge has the burden of arguing to demonstrate the magnitude and the transcendental impact of said reform, which would lead to having the Constitution being substituted by another, case in which it would not be enough to argue that a preexisting constitutional clause was breached, or to show that the reform created an exception to a higher norm or to show that it established a limitation or a restriction in respect of the prior constitutional order.

The amendment system to the Constitution in Colombia has three means ${ }^{2}$ consecrated in:

A bill that is initiated by Government, $5 \%$ of citizens eligible to vote, the territorial government or its representative institutions. The amendment process of this Legislative Act is performed by congress who must have 8 debates, in two 2 legislative periods, with the caveat that in the second legislative period the 4 debates must have an absolute majority in both chambers. Such legislative act may be challenged for its unconstitutionality by the people (i.e. 'acción pública de inconstitucionalidad') within the year following its passing into law. The initiative to file legislative bills may come from 10 members of congress, from $30 \%$ of city council members or provincial legislatures, or from a number of citizens that amount to $5 \%$ of those eligible to vote. Article 156 authorizes the Council of State only in its condition as officials to file bills pertaining to matters of its jurisdiction, ${ }^{3}$ and article 155 of the Political Constitution (CP $)^{4}$ foresees the possibility for the people i.e. citizens as well as for $30 \%$ the provincial legislatures and city councilmen to file constitutional reforms.

\footnotetext{
2 Articles 373, $374,375,376$ of Colombia's Political Constitution.

3 Ruling C-222 dated 1997, having as presenting Magistrate José Gregorio Hernández Galindo states precisely that only the Magistrates of the Council of State may present bills of legislative acts as per what is stipulated in I article 237 numeral 4 of the Political Constitution.

4 Article 155. A number of citizens that is equal to or greater than $5 \%$ of those eligible to vote on the respective date or thirty percent of city councilman or of members of the provincial legislature of the country may lodge bills to be turned into law or bills for constitutional reforms. The people's initiative will process by Congress, in accordance with what is stipulated in Article 163, for those bills that have been declared urgent. The proposing citizens in representation of the people shall have a right to designate a spokesperson that will be heard by both Chambers in all of its stages of the amendment process.
} 
A constitutional referendum must have a prior law that summons it, whose initiative must have the people or Government as actors, law which must be approved by an absolute majority in both chambers of congress. Such must have 4 debates and it has an automatic constitutional control for procedural defects. After such formalities have been performed the people are asked to vote, where there is a threshold of participation of one fourth of those eligible to vote and the majority of the voters must support the reform, case in which there must be a constitutional control if there is a challenge ${ }^{5}$.

A national constitutional assembly requires, likewise, a prior law, with citizens' initiative or an initiative from the institutions. Once the law is approved by an absolute majority in both chambers, the people are asked to vote if they want to summon such an assembly, the period and the composition that it determines. The law must be subject to an automatic constitutional control for procedural defects. Then, there is the consultation, where there must be a participation of at least one third of those eligible to vote. Once the amendment process has ended there will come the election of the delegates.

The control procedure of the legislative acts will be addressed in this document, as well as, the jurisprudence that has risen around the capacity of Congress to reform the Constitution and of the Court to control the procedural defects. That is why, the concept of defining axes will be reviewed, as well as, the concept of constitution substitution as notions that have not been developed by the original constituent, and in that measure, the Court has established a precedent. The concept of being unable to substitute will be reviewed in spite the fact that the Court has stated that there are no clauses written in stone, which are aimed at forging some fundamental principles, consolidating the defining axes and forging the theory of substituting that in the case of the Legislative Act 1 dated 2016 and of Ruling C 379 dated 2016, oscillated between the political and the juridical. ${ }^{6}$

The limits to constitutional amendments to which Albert makes a reference are summarized in 4 fundamental characteristics, the subject, the authority, the scope and the purpose, giving prevalence to the scope that should not exceed the Constitutional Scope ${ }^{7}$. Let's see how Colombia's Constitution and the Constitutional Court have set limits to constitutional amendments.

Articles 241, 242 and 378 of Colombia's Political Constitution.

Ruling C 699 dated 2016.

ALBERT, Richard. Constitutional Amendments Making, breaking, and changing constitutions. New York: Oxford University Press, 2019. p. 31-31, 78-79. 


\section{THE DEMOCRATIC PRINCIPLE OF HAVING JURISDICTION AND THE LIMITS TO THE CAPABILITY OF AMENDING THE CONSTITU- TION}

The power to reform the Constitution ${ }^{8}$ is a constituted power that must be circumscribed to the jurisdiction of reforming the Constitution. If the constituted power lacks this jurisdiction then there shall be a procedural defect, making the reform invalid, as per, the postulates of article 241 of Colombia's Political Constitution. Likewise, the constitutional reform substitutes the constitution; when it changes totally its fundamental constitutional content or when it changes essential components that identify the Constitution. Title XIII of the Constitution stipulated the reform faculty in the three acts, that is to say, the Legislative Act, the Approving act (i.e. 'Acto Refrendatario') and the Reforming Act which must come from a Constitutional Assembly. Yepes Arcila states that the Legislative Act headed by government and by congress is an act of minor intensity, in the measure that Congress is the representative of the original constituent. Electing people through a referendum is a means that enables citizens to participate in the constitutional reform proposals and here, there is a mayor capability to reform, and the people have - once again thru a National Constituent Assembly - full capacity to reform the constitution without restrictions since the constituent assembly is the sovereign power. ${ }^{9}$

The jurisdiction, therefore, is the materialization of the democratic principle given that it is the one which enables reviewing the validity of the amendment and doing so in accordance with the degree of jurisdiction with which they are bestowed to do so. The reform, thus, generates new constitutional norms. Also, the general clause on jurisdiction enables Congress only to have the capacity to develop the constitution, thus making a reference to the faculties that have being bestowed to it. Congress in virtue of Article 113 of Colombia's Political Constitution, has the faculty to develop the Constitution, and all other faculties that have not been attributed to other bodies of government are bestowed upon Congress, in accordance with enforcing Article 136 of Colombia's Political Constitution ${ }^{10}$.

\footnotetext{
8 Hernando Yepes Arcila, Ex-delegate to the "Asamblea Nacional Constituyente", in Ruling C 551 dated 2003, gave a lecture presentation around the power to reform and its limits.

9 Hernando Yepes Arcila, Ex-delegate to the "Asamblea Nacional Constituyente", in Ruling C 551 dated 2003, gave a lecture presentation around the power to reform and its limits.

10 Ruling C 543 dated 1998.
} 


\subsection{The democratic principle as a requisite to reform when amen- ding the constitution}

A transcendental aspect of the Legislative Act is to preserve the unity of matter, as an established requisite by the Constitution. Therefore, it is a requisite that the subject matter must have coherence with the essential nucleus of the legislative act and it must be tied to the content of the reform.

Also, the Democratic principal is also a procedural requisite that the Court must keep in mind when performing its procedural review. As a matter fact, the debates that guarantee the procedural formalities of legislative acts refer to voting the reform bill after having a debate on the subject matter. ${ }^{11}$ In reality it is the possibility of debating the bills that are geared to reforming the constitution, ${ }^{12}$ given that it is through debates that conclude which becomes the means how Congress expresses its will.

Debates are a guarantee of the democratic principle in the measure that if one of the debates were to be missing — four are needed for laws (art. 107 Colombia's Political Constitution) and eight are needed for Legislative Acts (art. 375 Colombia's Political Constitution) - , there would be a procedural defect of unconstitutionality in the amendment process and The Court must state it so, when exercising its control review duties. ${ }^{13}$

Debates and consensus may allude to party agreements prior to voting as a result of coalitions among groups that are in Congress. These coalitions, inevitably favor the adoption of measures that encourage governance, given that the dialogue between government and parliament is consolidated through open dialogue among party spokes people. ${ }^{14}$ Therefore, the Democratic principle is oriented fundamentally towards promoting debate, in spite of the prior agreements that generate commitments among those who favor or oppose the reform, generating a consensus. Undoubtedly, the liberty of legislative configuration and the democratic principal are the grounds for the legislative function.

A challenge of unconstitutionality by the people (i.e. "acción pública de inconstitucionalidad") is a guarantee of the Democratic principle given that, as the Court has stated in its jurisprudence, it must have clear, true, specific and sufficient reasons, as stipulated in the decree 2067 dated 1991. Those plaintiffs challenging must have the argumentative burden of exposing the structural axes that are being altered with the

\footnotetext{
11 As stipulated in articles 157 of the Constitution \& 176 of Law 5 dated 1992 as well as Article 227 of Law 5 dated 1992, that orders that the stipulations contained in the Norms of Congress referred in the ordinary legislative process which are compulsory when passing a legislative act.

12 Ruling C-222 dated 1997.

13 The Court stated in ruling C-222 dated 1997.

14 Abstain from voting Ruling C- 668 dated 2004 Magistrates Álvaro Tafur Galvis \& Marco Gerardo Monroy Cabra, published in the official Gazette of Congress number 378 of Thursday $31^{\text {st }}$ of July dated 2003.
} 
reform, the explanation of how the reform alters the structural axes and to what degree do they generate a substitution of the constitution.

In turn, the constitutional review control on legislative acts is a control on the nature, which is only exercised as per request and the ruling must only be on the challenges formulated by the plaintiffs who challenged the legislative act. In accordance with article 241-1 and 374 of the constitution, this was the thesis that was sustained for some time by the Court. As a matter fact, that is what was stated by The Court in ruling C-487 dated $2002^{15}$, when it ruled that the procedural defects in legislative acts were limited to the study of the challenges filed in the lawsuit. ${ }^{16}$

In time, the Court extended the theory of an integral review that applied for laws and for decrees turned into law, to that of legislative acts. In this sense the Court shall perform a review on all the procedural defects, although they may not have been invoked by the plaintiff. Therefore, the procedure of integral ${ }^{17}$ review of the legislative acts is a faculty of the Constitutional Court when ruling on procedural defects not only in its formation but also in its essence, in respect of the reformatory acts on the constitution. ${ }^{18}$ The Court clarifies that the adverb "only" of article 241-1 of Colombia's Political constitution cannot be taken literally, that is to say that the study by the Court cannot be reduced to only studying the formality but also studying the essence. And also, studying other dispositions. ${ }^{19}$

The Court ${ }^{20}$ when it performs its procedural analysis in the forming of legislative acts and it identifies procedural defects of jurisdiction, such may incur in a substitution of the constitution. In this sense, when the Democratic principal is not followed thoroughly, the Court performs a study on the essence, to identify if there was a configuration of a scenario of constitution substitution.

\footnotetext{
15 In this opportunity, having as presenting Magistrate Álvaro Tafur Galvis, the constitutionality of Legislative Act 01 dated 2001 was reviewed.

16 Having as presenting Magistrate Rodrigo Escobar Gil, in reviewing the lawsuit for partial unconstitutionality, challenging articles $1^{\circ}, 2^{\circ} \& 3^{\circ}$ Legislative Act 01 dated 2001. The same has been said in ruling C- 543 dated 1998 \& C- 614 dated 2002.

17 This topic is amply treated in Ruling C 668 dated 2004.

18 That was the constitutional control of Law 796 dated 2003, with which a referendum was convened and was placed to the people through a project of constitutional reform ruling C-551 dated 2003.

19 In this sense, the constitutional review study of the legislative act must be subject to the requirements stipulated in Article 157, 158, 160, 169 \& 375 of Colombia's Political Constitution. Also, of Law 5 dated 1992. Cfr, Ruling C-543 dated 1990.

20 There is ample jurisprudence around the scope of constitutional reforms by Congress and other questions around procedural defects, where the court assures that in such a case there must be an even greater argumentative burden considering that the Democratic principal must prevail. See Rulings C-1124 dated 2004, C-472 dated 2006, C-740 dated 2006, C-986 dated 2006, C-153 dated 2007, C-1058 dated 2008, A-274 dated 2012 y C-968 dated 2012.
} 


\subsection{The breach of the Democratic principal carries along a Constitu- tion substitution}

The Court has developed several guidelines to identify when a substitution of the constitution has occurred, following the defining axes. Without referencing to those clauses which are written in stone, that do not exist in Colombia's juridical framework, the defining axes are those principles that orient the constitutional framework and in that measure are unbreakable to the contrary, because they would be incurring in a constitution substitution. The jurisprudence ${ }^{21}$ has built an entire tradition around the main aspects that have been recognized to date to be inherent to the identity of the constitutional text. Therefore, there may not be any alterations through a simple reform. The main defining axes have been built around the democratic principle and around that of separation of powers. There is the administrative civil servant career and there is merit as being the main criteria to have access to a public post; there is the principle of equality, a two chamber configuration of the legislative body, the principle of alternating the exercise of power, and a system of checks and balances, all of these latter ones, expressing concretely the democratic principle per se.

Please review one of the many examples where the Court, in performing a judgement on substitution, ${ }^{22}$ concluded that the Legislative Act 1 dated 2011, affected the democratic principle and thus, made a substitution of the constitution. The Legislative Act 1 dated 2011, reformed Article 183 of Colombia's Political Constitution, in as far as losing a congressional seat, as a sanction to those Congress members who breached certain limits in exercising their role, as set forth by the Political Constitution. This legislative act excluded, from the consequences of losing the congressional seat, the actions of members of parliament who would have gone against the regimen of conflict of interest. As a matter of fact, the Legislative Act clarifies that their participation in the debate and their voting on legislative acts or constitutional reform, where the members of parliament can obtain a direct or indirect benefit, shall not be sanctioned with losing their congressional seat, given the high degree of generality of the characteristic of constitutional norms. The Court considered that a clause of this nature breached not only the democratic principle, public morals, the prevalence of the general interest, the duty of members of parliament to act in pursuit of justice and the common good, the possibility for their constituents to control the actions of their representatives, and along that same line, the institutional means of stripping away their congressional seat, as a means of debugging political customs. That is why it is so important to defend "the identity" and "the unity" of the constitution as a whole. Given that both are configured thru the institutions, the principles and the values of the Constitution. That is why the

\footnotetext{
$21 \quad$ Ruling C 249 dated 2012.

22 Ruling C- 1056 dated 2012.
} 
power to reform must preserve those values that have been consecrated in the Constitution, otherwise there would be a substitution.

The concept of substitution is a complex notion, that has not been defined by the Court, given that to a certain degree, it is a concept that has not been quite culminated and it is not exempt from political decisions. In the construct that is being made by the Court on the concept of substitution, it has awarded an unbreakable value to the concept of the constituent having the power that halts the reach of the constituted powers (or representative powers), granting a rigidity to the constitution that does not permit being denaturalized. These limits to substitution have been developed through Ruling C-971 dated 2004, and the Court has tried to draw a conceptual and a formal difference between "Reform" and "substitution". Thus, the substitution power ends up being very restricted and the power to reform is far more ample, although ambiguity still persists in the realm of reforms considering that it has less limits and it is turning into a means of more abusive power. ${ }^{23}$

\section{JUDGMENTS ON SUBSTITUTIONS: OSCILLATING BETWEEN AN AMENDMENT AND A DISMEMBERMENT}

As was pointed out by Albert the power to amend is one above all that does not exceed the scope of what was intended in the constitution, but there may be an intermediate point which he calls dismemberment ${ }^{24}$, which is more than an amendment but does not get to become a structural reform of the constitution.

Though, the court has made an effort to construct a theory on substitution, it still continues to be a random concept in the making. Identifying the limit between the amendment and the substitution is a task that requires care, where it is not always easy to delimit. A substitution is produced when there is a procedural defect in the jurisdiction to modify the Political Charter. The limits to the faculties in modifying the Political Charter were annunciated for the first time, ${ }^{25}$ indicating that the government bodies that had the power to modify the Political Charter were not bestowed with the power to repeal it, destroy it or subvert it. Transforming the content of the constitution is a different matter: ${ }^{26}$ "which implies that the changes are of such magnitude and transcendence that the original constitution was replaced by another, under the pretext of reforming it". The substitution refers to material changes that alter the identity of the

\footnotetext{
23 YEPES ARCILA Abstain from voting.

24 ALBERT, Richard. Constitutional Amendments Making, breaking, and changing constitutions. New York: Oxford University Press, 2019. p. 84-92.

25 Ruling C-551 dated 2003.

26 Ruling C-1200 dated 2003.
} 
constitution, and therefore, there is a rupture, ${ }^{27}$ "in such a way that the new constitution cannot be held as a continuation of the prior one, but rather as a different one, as a result of a new constituting $\operatorname{act}(\ldots)^{\prime 28}$.

In order to perform the judgment review in respect of constitution substitution, firstly, one must perform a study as to whether the defining axes has been definitively affected. In order to do so one must delineating what is a defining axis. Then one must establish if such an axis is projected throughout the constitution and the reasons why the axis is deemed defining, which together is considered to be a principal premise. The second stage deals with the manner in which the Reforming Act of the constitution impacts that defining axis and this analysis is a secondary premise. ${ }^{29}$ Once such a study has been performed and there is evidence of replacement or elimination, the Court proceeds to evaluate whether the new defining axis contravenes directly the Constitution in such a manner that it is incompatible with what was initially set forth in the constitution: this is what is the denominated as the premise of synthesis.

\subsection{Judgment on constitution substitution}

The court makes some conceptual precisions around the intangible and non-substitutable nature of the Constitution. Although the concept of 'clauses written in stone' does not exist in the Political Charter of Colombia the Court speaks of a judgment of untouchability, that refers to the criteria that the constituent had set forth, originally. It is a means to establish which are the intangible or untouchable norms and the possibility to perform an expensive interpretation or a restrictive one by constitutional judges. However, this criteria of being intangible is not present in Colombia's constitution and there is no clarity as to which norms are untouchable. The constituent did not exclude any norm from the power to be reformed, thus any of its content may be subject to reform. ${ }^{30}$

In as far as being non-substitutable, the court states that the existence in all constitutional frameworks of essential axes and definitory ones that if they were to be reformulated they would affect the identity of the constitution to such a degree that they would engender a different text. The Court assures that these premises are not present anywhere, in any article of the Constitution (because they are not intangible clauses) but they may be identified as of an analysis of the constitutional dispositions that constitute the different axes. Therefore, if such axes were to be modified or eliminated by the constituted powers (i.e. representatives) it would not be a legitimate

\footnotetext{
27 Ruling C-970 dated 2004.

28 Ruling C-970 dated 2004.

29 Ruling C -053 dated 2016.

30 Ruling C 288 dated 2012.
} 
exercise of the power to reform, but rather it would configure the act of constitution substitution. Thus, the untouchable nature responds to a greater rigidity of the constitution, while the non-substitution responds to the limit on the power to reform the constitution. From there, the non-substitution premise is grounded on the fundamental premise that substitution is not predicated among the competencies of the derived constituent and the reforms, in such a degree, are the reforms that a text would be different in comparison with the one drafted by the original constituent. ${ }^{31}$

With this, the Court affirms that the judgment on substitution does not want to raise principles, norms or rules to untouchable level, thus, jurisprudence has been constructing precedence on the matter. ${ }^{32}$ Juridical self restriction or self restraint permits fulfilling three objectives: protect the identity of the constitution, protecting it from arbitrary exercises of the power to reform, permitting the constitution to adapt to social and political changes, avoiding that under the exercise of performing a substitution test they could be incurring in a material control of constitutional reforms. That is how the court has expressed itself reiteratively. The Court has the jurisdictional duty of controlling legislative acts, but only in procedural defects, due to breaches in the amendment process as stipulated in the Constitution and in the norms that govern Congress. Therefore, the same court manifests that control does not fall on the material content of the Reforming Act. ${ }^{33}$ Self restriction seeks to avoid the subjectiveness in which the constitutional court Judge may incur.

Also, the Court affirms that there must be conceptual precision in respect of the substitution judgement when compared to other controls that the Court performs. Also, the Court is implementing a technique that in a manner of syllogism is made in three stages. The main premise is that there are aspects that define the identity of the constitution, then, the minor premise is that they perform the constitutional substitution test on the act. Such study is performed in respect of the defining axes that are being substituted or replaced. Then comes the third stage or third premise, or synthesis premise that contrasts between the main premise and the minor premise, to evidence whether there has been or not a procedural defect of jurisdiction, and confirming if in reality one is facing a substitution of the constitution. The Court's interpretation as of the analytical exercise of the Constitution, the Constitutionality Set (or 'Constitutional Block'), and other history criteria and jurisprudence has concluded that there are constitutional axes which have higher constitutional ranking, and which the State has the obligation to respect: guaranteeing and protecting human rights, the existence of a participative democratic framework, a Social State under the rule of law, the separation

31 Ruling C 288 dated 2012.

32 Ruling C- 1200 dated 2003.

33 Ruling C-543 dated 1998. 
of powers, and the autonomy and judicial independence, as well as, the checks and balances' system, an administrative career of public servants, the separation of powers and the reservation of the law. The Court adds that the constitution substitution is not a completed concept but rather "its test implies having to go back time after time to test the basic elements". ${ }^{34}$

The judgment on substitutions must differentiated from a material control on constitutionality of a reform act of the constitution, in the measure that the court must not perform this type of control, given that it ends up being illogical that the Court controls something that per se is reforming the content of the constitution. In addition to that, Article 241 of the Constitution excludes the possibility of a material control limiting the control to procedural defects. Therefore, any lawsuit presented on grounds of material control must result in an inhibiting ruling or in rejecting the acceptance of the lawsuit challenge. However, other types of analysis are possible, like resolving the challenges of the substitution and performing an abstract analysis on the content of the reform to study the implications of said reform, and whether eventually they generate a constitutional substitution, such as lack of jurisdiction or a procedural defect.

If the new norm does not encompass the general sense then there may be a constitution substitution. And, in this sense because there is no precept in the constitution that must be considered as essential, constitutional judges are the ones who are called to develop such guidelines through jurisprudence.

As a matter of fact, Albert alludes to constitutional changes that are more than amendments. These are changes that transform the Constitution and orient it towards new directions. This new orientation does not create a new constitution, but it is a change that deliberately modifies its content, profoundly (in something). In Colombia the constitutional theory of dismemberment ${ }^{35}$ does not anchor itself on a formalist understanding of the constitution. Albert describes it as a middle ground between an amendment and a substitution, as if it were more than an amendment but less than a new constitution. The specificity of this dismemberment is that the constitution remains but an essential aspect of it is changed, such as a right is changed, or a structure or a procedure is changed that gave identity to the constitution. The political agreement with the FARC is a scenario that best describes the dismemberment, in terms of enforcing the Colombian constitutional structure. When the Court backed the procedure to Fast track and to Incorporate such as a constitutional amendment, it transformed the procedure originally stipulated in the Constitution. This unequivocally obeyed the political overtone of the agreement and bowed to pressures from the executive, who inevitably wanted to implement the agreement quickly.

34 Ruling C 332 dated 2017.

35 ALBERT, Richard. Constitutional Amendments Making, breaking, and changing constitutions. New York: Oxford University Press, 2019. p. 84-92. 


\subsection{Dismemberment and Fast track}

Legislative Act Number 1 dated 2016, ${ }^{36}$ added one transitory article to the constitution where it is foreseen to have a legislative exceptional procedure for a period of six months. In this Legislative Act it is stipulated that all projects associated with peace shall be of government initiative, because the purpose is to facilitate and to ensure the implementation of the Final Accord. ${ }^{37}$ Likewise, procedural changes in the acts of reform to the Constitution stipulate that the first debate of the bill would be held in a respectively joint chambers' session of permanent constitutional commissions, and the second debate shall be held in plenary sessions of both chambers. The bills shall be approved by absolute majority in one round, since there will only be four debates, where there shall be only 8 days in the middle between one and the other chamber. These modifications to each bill shall be done with the backing of the national government. There shall be an automatic control on constitutionality for procedural defects in the drafting. This legislative act has four more articles, where they grant presidential faculties to issue decrees that will be turned into law (Article 2), and it creates additional multiyear investment plans for the next 20 years. ${ }^{38}$

In addition to that, on behalf of the right to peace, they will include a special legislative procedure to approve the Final Accord and it must be incorporated into the juridical framework. The special legislative procedure or Fast Track will have some special procedural formalities in processing the bill and in approving the law. The Legislative Act foresees initially sending to Congress a bill that will be processed as an ordinary law, lodging the bill at the secretary of the senate and publishing it and debating it in the joint constitutional commissions of the Senate and the House, voting and debating it in plenary sessions of the Senate; and debating it in the plenary session of the House. This processing of the bill among commissions and plenary sessions will be an 8 day process. Votes can only be for approval or denial of the entire text; constitutional control of the law approving the Special Agreement will be performed; there will be presidential sanctioning and publication in the Official Gazette; this will be during a six month period. The Constitution review control will be automatic and it will be unique. The expiration term of the Legislative Act shall be as of its popular approval by a plebiscite.

The challenging lawsuit of unconstitutionality requests declaring a constitution substitution. In effect, reducing to 4 debates a constitutional reform, as well as reducing the number of rounds from 2 to 1 is going against the Constitution. That is why raising this to the level of a Legislative Act with an ordinary law substitutes the constitution in

\footnotetext{
36 The development of the norms of the Final Accord.

37 In addition to that, the plaintiffs suing other articles of the legislative act, given that in that very legislative act, the final cord is assimilated to being an international peace treaty.

38 This fund foresees that there will be an investment plan within the national development plan, with the intent of giving priority to the zones that were affected by the conflict. (art. 3).
} 
article 375, given that it modifies the structural elements of constitution reform and of the primary constituent. This modality that is so called fast track overlooks the principle of separation of powers given that it extra limits the executive powers in matters of legislative powers, and it limits the constitutionality review control power of the Court in as far as under the principle of double Jeopardy it can no longer review again the legislative act, and it impedes the court from reviewing aspects of the legislative act that were not subjected to the effect of double Jeopardy tried matters. ${ }^{39}$

The Court declared unconstitutional what was stipulated in Paragraph h) and j) of article $1^{\circ}$ of Legislative Act 1 dated 2016 because they substituted the principle of separation of powers. They stated that there was a suppression of the capability to deliberate and to decide by Congress, both in the creation of the law and in amending the constitution, where the Act challenged in the lawsuit had been transferred to the executive.

Additionally, the Court in ruling C-699 dated 2016 also analyzed Legislative Act 1 dated 2016 and stated specifically that constitutional amendments that develop transitional justice means are not in genere substitutions of the constitution. In effect, they affirmed that although transitional measures may be adopted and some that reform the constitution that in certain aspects substitute the Charter as long as it is transitional, situation that may arise when through such means one replaces a definitive axis of identity of the constitution, as could be the case in terms of separation and of balance of powers. ${ }^{40}$

However, the court sustained the abbreviated procedure or fast track, reducing the number of debates for approval of the legislative acts. The Final Accord, being a political act, requires the work of implementing norms, and that is bestowed upon Congress, given that they have the democratic mandate of being representatives. In that degree the debate grants full legitimacy to its deliberating and decision-making activities, which are materialized in the general clause of legislative jurisdiction.

This decision, the Court clarified, is to be enforced in the future, with which the legislative acts that were approved under the procedure of fast track, like amnesty or the creation of the Special Justice for Peace (JEP for its initials in Spanish), shall remain and not be modified, although they went through the review via automatic control of constitutionality. This situation is a clear example of dismemberment, an abbreviated procedure to introduce constitutional reforms with the intent of reducing the number of debates and weakening the scenario of participation as well as of democratic representation. Things as they are, the Special Legislative Procedure for Peace consecrated in

39 The plaintiffs consider that Article $1^{\circ}$ of Legislative Act N. 01 dated 2016 breach article 113, 241, 243, 374, $375 \& 379$ of the constitution.

40 Ruling C-699 dated 2016. 
the Legislative Act 01 dated 2016 was sustained as a rapid pathway, special, exceptional and transitory. The court sustained:

that it fulfills the principles of celerity, legislative efficacy and efficiency as well as having the purpose of being agile and of guaranteeing a timely implementation of the Final Accord, whose constitutional thelos is to turn effective the right to peace via the reduction of the terms in passing a law and in passing legislative acts, that may only be used to developed what was agreed in the Final Accord. ${ }^{41}$

In the aforementioned ruling that had already analyzed the Legislative Act number 1 dated 2016, the court affirmed that the abbreviated procedure of formalities for legislative acts was not a substitution of the constitution given that such procedure of fast track was not going alone, because there were 3 stages intervening. One of people approval, a parliamentary stage and one instance of automatic constitutional control. That justified the special and abbreviated procedure in Congress. ${ }^{42}$ At the end of the aforementioned ruling they added that Legislative Act number 1 dated 2016,

did introduce a change in the reform procedures by Congress, when contemplating the special mechanism to produce legislative acts with a parliamentary stage constituted by four debates, an absolute majority and an 8 day transition between the two chambers. Notwithstanding, this change does comply with the jurisdictional limits of the power to reform the constitution. ${ }^{43}$

However, the concept of popular approval to which the court alludes in this ruling shows a series of argumentative maneuvers that do not correspond to the means foreseen in Article 103 of the Political Charter, or to the concepts developed before by the Court in respect of the means of participation.

The abstaining from voting by Magistrate Luis Guillermo Guerrero, who distanced himself from the decision, describes in a forceful manner this situation. The magistrate distanced himself from the majority decision that altered the principle of separation of powers, thus altering the venues of collective construction and of generating a permanent and a continuous venue for consensus. Effectively, this ruling came after having a plebiscite that was held on October $2^{\text {nd }}$ of 2016, when the people in their majority voted NO to the Peace Accord. The Court in Ruling C 379 dated 2016 had said that if this were to happen there would have to be a new summoning of the people. But, the Government decided that there would not be such summoning and that it would

\footnotetext{
41 Ruling C 6302017.

42 Ruling C 699 dated 2016.

43 Ruling C 699 dated 2016.
} 
award such faculty to Congress on behalf of the people, to vote the approval of the Peace Accord.

The abstention from voting by Magistrate Guerrero alluded precisely to this, in stating that they were replacing the direct participation of the people with an interpretative role of Congress that is subject to the play of majorities. ${ }^{44}$

lestimate that by doing without a true people approval, one is permitting that the signed accord between government and an armed outlaw group acquires quasi constituent connotations, and as far as, by disposition of the very "Acto Legislativo 01 de 2016" it ends up being binding in the implementation phase and its development imposed via Fast track, which stripped away venues for deliberation. In this manner, central aspects, backed by constitutional rigidity, are performed by Government in accordance with what was previously stipulated in the Final Accord, which presents practically immutable connotations. ${ }^{45}$

Additionally, what the Legislative Act 01 dated 2016 foresees are structural reforms that include topics of much controversy like the Special Jurisdiction for Peace, the agrarian structure, the political participation of former combatants. Limiting the venues for deliberation and the participation of Congress would only be legitimate if the accord would have been approved by the people in a direct manner and through the means that the constitution foresees for such cases. ${ }^{46}$ The one who abstained from voting added that any means that would permit establishing in a true and unequivocal manner that there is actually a consensus of the people around the peace accord ${ }^{47}$ would be valid, but, not being at the unilateral decision taken by Government or by Congress. What this is doing is "to be unaware of the decision of the majority in the plebiscite dated October 2, and that permits accentuating the social price tags that result from pushing through a process without having had around it the indispensable consensus, as grounds for a true peace that would be stable and long lasting".48

\section{CONCLUSION}

Albert describes the power of the courts as one to safe guard the content of the constitution and to validate constitutional changes that are made by the constituted powers, which may go over and beyond the limits of the constitution. It is the doctrine

44 Abstain from voting Luis Guillermo Guerrero Ruling C 699 dated 2016.

45 Abstain from voting Luis Guillermo Guerrero Ruling C 699 dated 2016.

46 Article 103 of Colombia's Political Constitution.

47 Abstain from voting Luis Guillermo Guerrero Ruling C 699 dated 2016.

48 Abstain from voting Luis Guillermo Guerrero Ruling C 699 dated 2016. 
of unconstitutionality of constitutional reforms as the triumph of democracy. ${ }^{49}$ Likewise, citing Ran Hirschl ${ }^{50}$, this scenario that grants Constitutional Courts the capacity to intervene in the political realm is a clear example of judicializing politics. This scenario shows how Colombia's Constitutional Court handle the incorporation of the political agreement with the FARC, to the constitutional framework and Colombia's juridical framework. Rulings C-699 dated 2016 \& C-332 dated 2017, have an enormous political component in the measure that they incorporate the political agreement to the legal framework, which required strategies that unequivocally gave rise to these decisions. The Court in ruling C-332 dated 2017 declared unconstitutional part of the Legislative Act N. 1 dated 2016 that eliminated some of congress' duties, but in order to incorporate the peace agreements, sustained the fast track. With such, it not only alters the content of the article 375 with the will to reduce the number of debates of legislative acts and to diminish the participation as foreseen in the Constitution for constitutional amendments, something that is very risky considering the climate of a majority in Congress and a strong opposition to the peace agreement, but yes to its content. Additionally, the non-retroactive nature of fast track makes legislative acts that were voted before Ruling C 332 dated 2017, to remain current and in force. Several elements that more than amending, substitute the constitution, which cannot be understood from the juridical perspective but they can be understood from the political perspective.

\section{REFERENCES}

ALBERT, Richard. Constitutional Amendments: Making, breaking, and changing constitutions. 1. ed. New York: Oxford University Press, 2019.

49 ALBERT Richard. Constitutional Amendments Making, breaking, and changing constitutions. New York: Oxford University Press, 2019. p. 217.

50 ALBERT, Richard. Constitutional Amendments Making, breaking, and changing constitutions. New York: Oxford University Press, 2019. p. 218. 